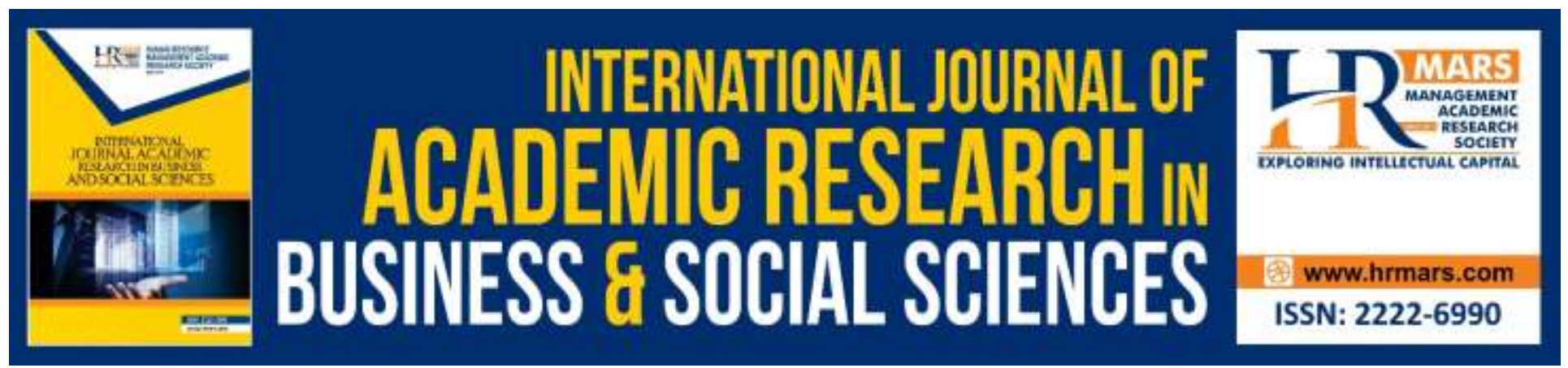

\title{
The Effectiveness of Spaced Learning as a Pedagogical Strategy in Enhancing Student Learning and Motivation
}

Jessnor Elmy Mat-jizat, Bahijah Abas, Mahaliza Mansor, Khalizul Khalid

To Link this Article: http://dx.doi.org/10.6007/IJARBSS/v10-i5/7221

DOI:10.6007/IJARBSS/v10-i5/7221

Received: 08 March 2020, Revised: 19 April 2020, Accepted: 24 April 2020

Published Online: 20 May 2020

In-Text Citation: (Mat-jizat et al., 2020)

To Cite this Article: Mat-jizat, J. E., Abas, B., Mansor, M., \& Khalid, K. (2020). The Effectiveness of Spaced Learning as A Pedagogical Strategy in Enhancing Student Learning and Motivation. International Journal of Academic Research in Business and Social Sciences, 10(5), 494-506.

Copyright: @ 2020 The Author(s)

Published by Human Resource Management Academic Research Society (www.hrmars.com)

This article is published under the Creative Commons Attribution (CC BY 4.0) license. Anyone may reproduce, distribute, translate and create derivative works of this article (for both commercial and non-commercial purposes), subject to full attribution to the original publication and authors. The full terms of this license may be seen

at: http://creativecommons.org/licences/by/4.0/legalcode

Vol. 10, No. 5, 2020, Pg. 494 - 506

http://hrmars.com/index.php/pages/detail/IJARBSS

JOURNAL HOMEPAGE

Full Terms \& Conditions of access and use can be found at http://hrmars.com/index.php/pages/detail/publication-ethics 


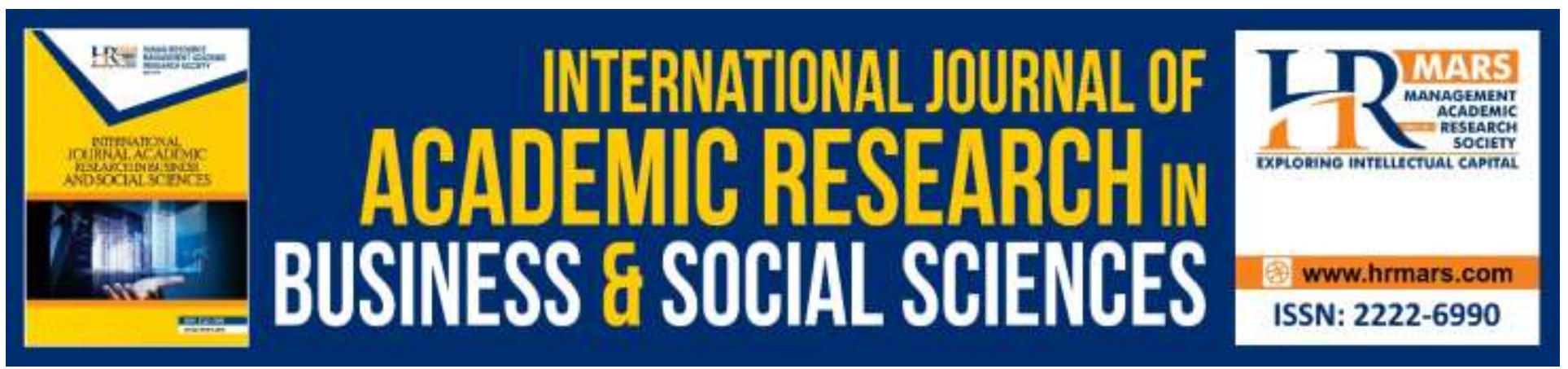

\title{
The Effectiveness of Spaced Learning as A Pedagogical Strategy in Enhancing Student Learning and Motivation
}

\author{
Jessnor Elmy Mat-jizat, Bahijah Abas, Mahaliza Mansor, Khalizul \\ Khalid
}

Universiti Pendidikan Sultan Idris, Malaysia.

\begin{abstract}
The aim of this study is to explore the effectiveness of Spaced Learning technique as a teaching and learning method for students in Higher Learning Institutes (HLIs). Amidst the rapidly changing technological environment, creating long-term memories is still at the core of education. Spaced Learning is a learning method in which highly condensed learning content is repeated three times, with two 10-minute breaks during which distractor activities such as physical activities are performed by the students. It was suggested that spacing learning over time helps people learn more quickly and remember better. This study examines the impact of using Spaced Learning technique on students' performance and motivation to learn. A quasi-experimental research design was implemented. Two groups of students were chosen, and both were taught on the same pre-identified topic, albeit using two different methods: 1) the conventional way, and 2) using Spaced Learning technique. A pre-test and post-test were conducted to both groups. The students' motivation and performance results were analysed and discussed.
\end{abstract}

Keywords: Spaced Learning, Higher Education, Pedagogy, Learning, Motivation.

\section{Introduction}

Creating long-term memories is at the core of education. Yet it wasn't until 2005 that a key discovery was published in Scientific American explaining how long-term memories are formed in the brain (Fields, 2005). Fields found that constant stimulation of the brain cell did not make it switch on. The length of cell stimulation was not vital for long-term memories, but the gap between stimulation was. This is known as Spaced Learning.

Studies of human memory have shown that we remember more when learning is spaced over time rather than crammed together in a single session. Typically, these studies have focused on learning short items, such as words or phrases in a foreign language, with increasing spaces between attempts to recall the items. 
INTERNATIONAL JOURNAL OF ACADEMIC RESEARCH IN BUSINESS AND SOCIAL SCIENCES Vol. 10, No. 5, May, 2020, E-ISSN: 2222-6990 ㄷ 2020 HRMARS

The way this is thought to work is that each recall session stimulates the learner's short-term memory for the item and its new association, until these become fixed in long-term memory. The method is generally successful, providing the student is willing to stick with it. However, the learning takes place over days and has been limited to building connections between words, phrases or images.

New research into the neuroscience of learning has now identified how long-term memories can be made in minutes rather than days and for complex topics, not simply basic associations. In brief, the human brain contains around 85 billion cells, or neurons. Each can be connected with up to 10,000 other neurons through synapses, tiny gaps that transmit electrical or chemical impulses. As well as being briefly activated by stimuli such as sights and sounds, connections between synapses can be strengthened by persistent chemical changes. These connections are the basis of long-term memories.

Experiments with animal cells have shown that the chemical strengthening between neurons happens while learning and again later, including during sleep. In one study, brain cells removed from a rat hippocampus (the part of the brain used to consolidate short-term to long-term memories) were stimulated with electricity. The researchers found that three bursts of stimulation, with 10-minute spaces between them, produced more active connections between synapses than one long period of stimulation. The spaced bursts also produced a protein in the cells that is observed when long-term memories are being made.

A few studies of human brain activity while learning have been carried out. One of these examined magnetic resonance imaging (MRI) brain scans of humans after they had tried to memorise 120 novel pictures of faces (Xue, Mei, Chen, Lu, Poldrack, \& Dong, 2011). In the 'massed learning' condition each face was presented multiple times, followed by the next face. In the 'spaced learning' condition, the faces were presented in sequence, one after the other. The study showed that spacing out the faces by showing a sequence of different ones produced more activity in the part of the brain linked to face recognition than the massed presentation. There have not yet been any attempts to study effects on the brain of longer spaces (such as ten minutes) between periods of learning.

The evidence so far, mainly from experiments with animal brain cells, suggests that a period of learning stimulates connections between brain cells. It takes time for the chemical bonds between synapses to strengthen. Trying to learn too much in one session may not give the brain time to embed the knowledge in long-term memory. The animal cell experiments suggest a space of ten minutes between learning episodes.

Taking on the findings of this discovery, Kelley and Whatson (2013) had conducted a study on 440 students aged between 13 to15 in an urban secondary school in England. The study was conducted in order to identify whether repeated stimuli separated by timed spaces without stimuli can initiate Long-Term Potentiation (LTP) and long-term memory (LTM) encoding. LTP is a persistent strengthening of synapses in the brain based on recent patterns of activity. These are patterns of synaptic activity that produce a long-lasting increase in signal transmission between two neurons (Nicoll, 2017). While LTM is what you use to make sense of and give meaning to what you are doing now. It is the repository for more permanent knowledge and skills and includes all things in memory 
that are not currently being used but which are needed to enable understanding (De Bruyckere, Kirschner, \& Hulshof, 2015).

Using a formula of 10-minute breaks between three intensive sessions of 15-20 minutes teaching, Kelley and Whatson (2013) found that Spaced Learning is more efficient in comparison to standard teaching. For each of the three 15-20 minutes intensive sessions, teaching materials were repeated but presented differently, deepening and extending it. During the 10-minute breaks, distracter activities such as juggling, throwing balls or animals modelling out of Play-Doh were carried out. When compared between the experiment group who were taught using the Spaced Learning technique for one-hour, with the control group who learned the same topic for four months, the findings showed no significant difference in student achievement. This means that using Spaced Learning, students were able to achieve the same result as the group of students who studied using typical teaching methods for four months.

This method has been tested successfully in schools in UK for students aged 13-15. It would be interesting if Spaced Learning could be implemented in Higher Learning Institutes (HLIs) in Malaysia.

\section{Spaced Learning for Education}

Kelley and Whatson (2013) have designed a method for spaced teaching of curriculum topics. The teaching consists of three 20-minute sessions, with 10-minute breaks between them.

- Session 1 (20 minutes) Teacher gives a rapid presentation of a new topic.

- Break (10 minutes) Students engage in physical activity, such as juggling or modelling.

- Session 2 (20 minutes) Students actively recall key concepts from the presentation.

- Break (10 minutes) Students engage in physical activity, such as juggling or modelling.

- Session 3 (20 minutes) Students apply the knowledge through problem exercises.

Kelley and Whatson ran trials of their teaching method with students aged 13-15 who were learning Biology in a UK school. In one trial, students studied an entire first Biology course through spaced learning over a period of 90 minutes. Their exam performance was compared to a control group of students who studied the course in standard lessons over four months. There was no significant difference in exam scores between students who had done spaced learning in a single day and those who studied over four months.

\section{Generational Learning Styles}

Learning styles were not only differed based on the different cognitive styles and preferences. The differences in generation also play an important role in educating the young minds. Those who were born after 1990's is known as the Generation Z. These generations never experienced life before the Internet. They were accustomed to multimedia and doing everything at the same time. Generation $Z$ youth have become accustomed to interacting and communicating in a world that is connected at all times (Turner, 2015).

In their study, Chun, Dudoit, Fujihara, Gerschenson, Kennedy, Koanui, Ogata and Stearns (2016) found that Generation $Z$ usually portrays these preferences in learning: 
- there is a noticeable difference in the shortened attention span of these learners. This generation has been exposed to a constant stream of short segments of information and clips not more than six seconds including Facebook posts and Youtube videos. As a result, they often exhibit a short attention span. A related noticeable impact is on the ability of these learners to concentrate and focus on longer, more complex or involved problems;

- the use of multimedia devices has resulted in an increased development of the visual ability portion of these learners' cognitive functions. Visual forms of learning, such as picture, video games, and videos seem to be more interesting to these learners and more effective; and

- they have easy access to information, which creates an expectation of instant results and constant feedback. They expect answers immediately and may often not want to spend the time to ensure the legitimacy or reliability of the sources they find.

Current educational systems must change in response to a new generation of young people. Current students have been variously described as disappointed (Oblinger, 2003), dissatisfied (Levin \& Arafeh, 2002), and disengaged (Prensky, 2005). Brown (2000), contends “today's kids are always "multiprocessing" - they do several things simultaneously - listen to music, talk on the cell phone, and use the computer, all at the same time" (p. 13). It is also argued that the new generations are accustomed to learning at high speed, making random connections, processing visual and dynamic information and learning through game-based activities (Prensky, 2001). It is suggested that because of these factors young people prefer learning styles that allows them to explore and to actively test their ideas and create knowledge (Brown, 2000).

\section{Research Aim and Objectives}

This study examines whether there were differences in students' academic performance and motivation in learning using two different learning styles. The experiment group where taught using Space Learning, while the control group where using conventional teaching method.

To ensure that the research aims were met, the research objectives for this study were to:

i. $\quad$ identify the difference in students' performance between group using conventional method and group using Spaced Learning technique; and

ii. identify the difference in students' motivation between group using conventional method and group using Spaced Learning technique.

Two hypotheses have been developed based on the research questions, which were:

Ho1: There is no significant difference in students' performance between group using conventional method and group using Spaced Learning technique.

Ho2: There is no significant difference in students' motivation between group using conventional method and group using Spaced Learning technique. 
INTERNATIONAL JOURNAL OF ACADEMIC RESEARCH IN BUSINESS AND SOCIAL SCIENCES Vol. 10, No. 5, May, 2020, E-ISSN: 2222-6990 @ 2020 HRMARS

\section{Methodology}

A quasi-experimental research design was employed. A three-phase quasi-experimental design were carried out (Levy \& Ellis, 2011; Campbell \& Stanley, 1963). The first phase involves a pre-test to determine the student's prior domain knowledge about the pre-identified topic which the class is going to be taught. The students were also given a set of questionnaires on their current motivation to learn the subject. The students were then divided into two groups (control and treatment).

The second research phase were the 'teaching period' in which the treatment group were taught using Spaced Learning technique, while the control group were taught using the conventional methods (e.g.: mass lecture).

On the final research phase, the students were given the same test as the pre-test but arranged in a different order. They were also given the same questionnaire on current motivation to learn the subject. The quasi-experimental research design is illustrated below:

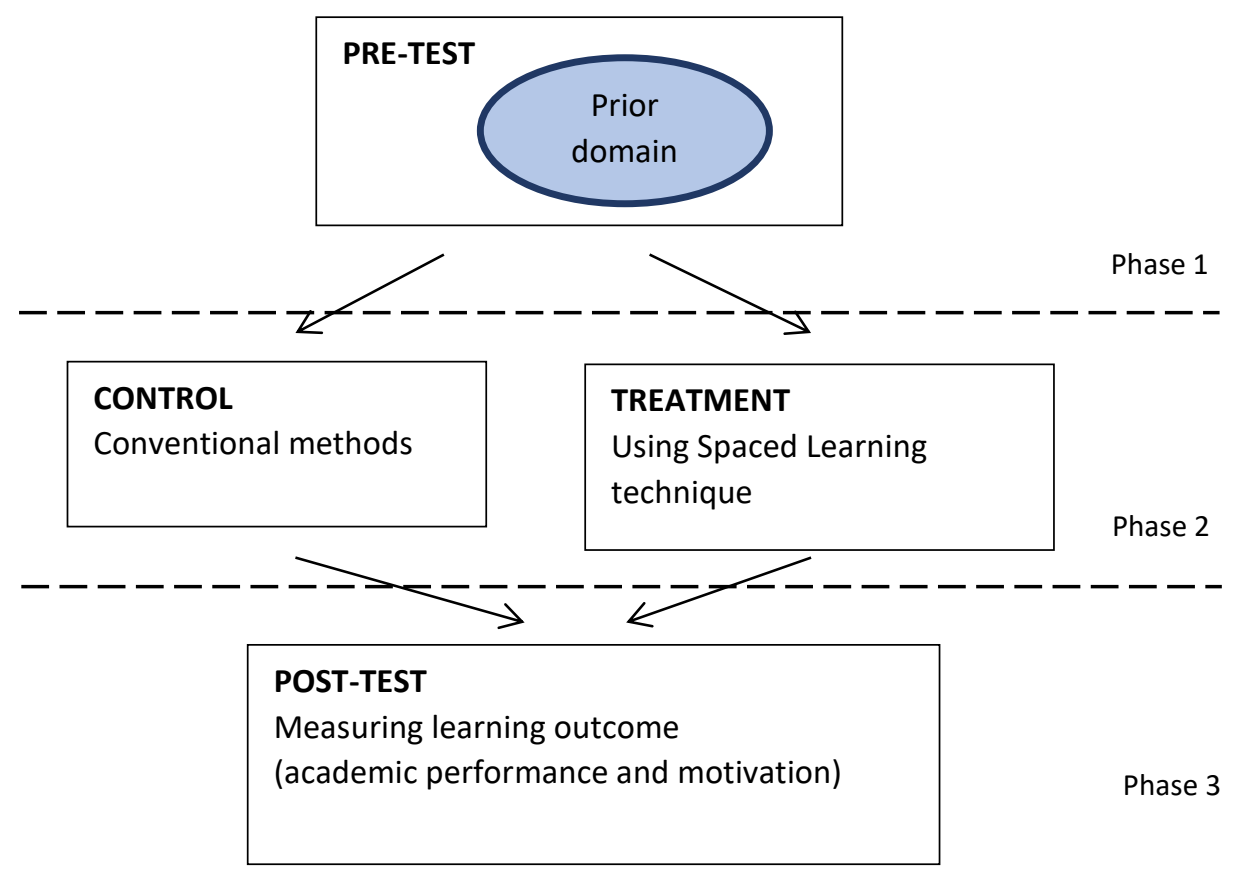

\section{Research Instrument}

Two types of instruments were used in this study. The first one was a questionnaire which was used to measure the participants' motivation to learn, and the second instrument was a student performance test questions which was used to assess the participants' performance score.

\section{i. Student Performance Test Question}

The student performance test question was designed by the course (Business Mathematics course) lecturer based on the topic of Exponential and Logarithmic Functions. The test question was given to both the experiment group and control group twice. The first time, it was given prior to the topic been taught to any of the classes. This was to identify the initial knowledge of the chosen topic that each of the participants have. The second time, the same question was re-arranged in order to reduce testing bias. In a quasi-experimental study, the effect of giving the pre-test may affect the outcomes 
INTERNATIONAL JOURNAL OF ACADEMIC RESEARCH IN BUSINESS AND SOCIAL SCIENCES

Vol. 10, No. 5, May, 2020, E-ISSN: 2222-6990 @ 2020 HRMARS

of the second test (Campbell \& Stanley, 1963). Rearranging and changing the order of the questions may help in reducing bias.

ii. Motivation to Learn Questionnaire

The motivation to learn instrument was adapted from Ersoy and Oksuz (2015), who designed the questionnaire to determine the motivation of primary school students towards learning mathematics. Based on their analysis, the instrument was highly reliable and has adequate power to predict the item total score (Ersoy \& Oksuz, 2015). The instrument is suitable for evaluating motivation in general, but it does not differentiate between intrinsic motivation and extrinsic motivation. The instrument was originally consisting of 33 questions, with 3-point scale.

\section{Data Analysis and Findings}

The classes chosen for this study were identified as Group A (Experiment Group) and Group B (Control Group). The naming of the group does not relate to the actual lecture group for this class. The whole class were chosen as the participant in this study as to avoid any bias in the data collected. Table 1 below showed the information on gender and academic background for both classes.

Table 1. Respondents' Gender and Academic Background

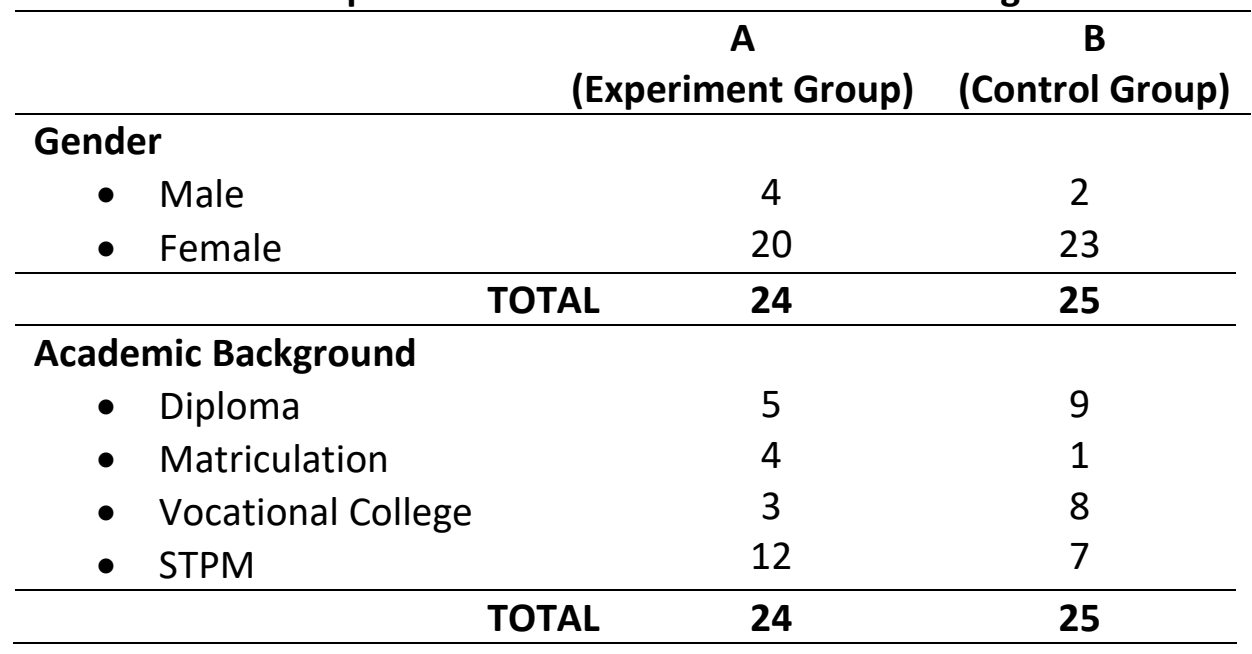

For this study, two hypotheses had been identified to be tested. The findings for each hypothesis were described separately.

\section{Hypothesis 1}

$\mathrm{H}_{0} 1$ : There is no significant difference in students' performance between group using conventional method and group using Spaced Learning technique.

In order to ensure that the students in both classes were equally divided academically, MannWhitney $U$ Test was conducted upon their pre-experiment performance score. The student performance test instrument was administrated to students in both classes prior to the lesson being delivered. The findings were described in Table 2 below. 
INTERNATIONAL JOURNAL OF ACADEMIC RESEARCH IN BUSINESS AND SOCIAL SCIENCES

Vol. 10, No. 5, May, 2020, E-ISSN: 2222-6990 @ 2020 HRMARS

Table 2. Mann-Whitney U Test on Students Performance

PerformanceBefore

\begin{tabular}{lll}
\hline Group & N & Median \\
\hline Group A & 24 & 0.000 \\
Group B & 25 & 0.000 \\
\hline Total & 49 & 0.000 \\
\hline & & Perf_before \\
\hline Mann-Whitney U & 290.500 \\
Wilcoxon W & 590.500 \\
Z & -0.362 \\
Asymp. Sig. (2-tailed) & 0.717 \\
\hline
\end{tabular}

a. Grouping Variable:

Group

Sig. equals $<=0.05$

Most of the students did not have good prior knowledge on the topic. They were mostly unable to give any correct answer to the questions. However, there was no significant difference in performance score for both the experiment class and control class in this pre-experiment stage. A Mann-Whitney $U$ Test revealed no significant difference.

To calculate the effect size, a formula of $r=Z$ / sqrt N was use, where according to Cohen (1988), criteria of $0.1=$ small effect, $0.3=$ medium effect, $0.5=$ large effect. The Mann-Whitney $U$ Test revealed no significant difference in performance of Group A- Experiment $(M d=0, n=24)$ and Group B - Control $(M d=0, n=25)$, where $U=290.5, Z=-0.362, p=0.72$ and $r=0.05$.

To test $\mathrm{H}_{0} 1$, Wilcoxon Signed Rank Test was conducted on students' motivation score in both classes by comparing score for post-experiment to pre-experiment. The findings were described in Table 3 and Table 4 below. 
INTERNATIONAL JOURNAL OF ACADEMIC RESEARCH IN BUSINESS AND SOCIAL SCIENCES

Vol. 10, No. 5, May, 2020, E-ISSN: 2222-6990 @ 2020 HRMARS

Table 3. Wilcoxon Signed Rank Test Results on Students' Performance (Control Group)

\begin{tabular}{llrrr} 
Ranks & & N & Mean Rank & $\begin{array}{r}\text { Sum of } \\
\text { Rank }\end{array}$ \\
\hline PerformanceAfter- & Negative Rank & $0^{\text {a }}$ & 0.00 & 0.00 \\
PerformanceBefore & Positive Rank & $25^{\text {b }}$ & 13.00 & 325.00 \\
& Ties & $0^{c}$ & & \\
\cline { 2 - 5 } & Total & 25 & & \\
\hline
\end{tabular}

a. PerformanceAfter < PerformanceBefore

b. PerformanceAfter $>$ PerformanceBefore

c. PerformanceAfter $=$ PerformanceBefore

\begin{tabular}{lc}
\hline & $\begin{array}{c}\text { PerformanceAfter- } \\
\text { PerformanceBefore }\end{array}$ \\
\hline Z & $-4.398^{\mathrm{a}}$ \\
Asymp. Sig. (2-tailed) & 0.000 \\
\hline
\end{tabular}

a. Based on negative ranks.

In the control group, the Wilcoxon Signed Rank Test revealed a statistically significant increase in student's performance where, $Z=-4.398, p=0.000$, with a large effect size $(r=0.622)$.

Table 4. Wilcoxon Signed Rank Test Results on Students' Performance (Experiment Group)

\begin{tabular}{llrrr} 
Ranks & & & & \\
\hline & & Mean Rank & $\begin{array}{r}\text { Sum of } \\
\text { Rank }\end{array}$ \\
\hline PerformanceAfter- & Negative Rank & $0^{\text {a }}$ & 0.00 & 0.00 \\
PerformanceBefore & Positive Rank & $24^{\text {b }}$ & 12.50 & 300.00 \\
& Ties & $0^{c}$ & & \\
\cline { 2 - 5 } & Total & 24 & & \\
\hline
\end{tabular}

a. PerformanceAfter < PerformanceBefore

b. PerformanceAfter $>$ PerformanceBefore

c. PerformanceAfter $=$ PerformanceBefore

\begin{tabular}{lc}
\hline & $\begin{array}{c}\text { PerformanceAfter- } \\
\text { PerformanceBefore }\end{array}$ \\
\hline Z & $-4.323^{\mathrm{a}}$ \\
Asymp. Sig. (2-tailed) & 0.000 \\
\hline
\end{tabular}

a. Based on negative ranks.

In the experiment group, the Wilcoxon Signed Rank Test also revealed a statistically significant increase in student's performance where, $Z=-4.323, p=0.000$, with a large effect size $(r=0.624)$. 
INTERNATIONAL JOURNAL OF ACADEMIC RESEARCH IN BUSINESS AND SOCIAL SCIENCES

Vol. 10, No. 5, May, 2020, E-ISSN: 2222-6990 @ 2020 HRMARS

Based on both findings, we could see that there was significant difference in students' performance for both the experiment group and control group. However, the difference of performance for the experiment group have only a small amount of difference in terms of effect size $(r=0.624)$ compared to the control group ( $r=0.622$ ). $\mathrm{H}_{0} 1$ was rejected.

\section{Hypothesis 2}

$\mathrm{H}_{0}$ 2: There is no significant difference in students' motivation between group using conventional method and group using Spaced Learning technique.

To ensure that the students in both classes were equal in terms of motivation to learn before the experiment was implemented, a Mann-Whitney $U$ Test was conducted upon their pre-experiment motivation score for both the experiment and control group. This step is important in order to determine if there exist any respondent selection bias, which could affect the validity of data analysis. The findings were described in Table 5 below.

Table 5. Mann-Whitney U Test on Students Motivation to Learn

MotivationBefore

\begin{tabular}{lll}
\hline Group & N & Median \\
\hline Group A & 24 & 55.000 \\
Group B & 25 & 55.000 \\
\hline Total & 49 & 137.000 \\
\hline
\end{tabular}

\begin{tabular}{ll} 
& Perf_before \\
\hline Mann-Whitney U & 281.000 \\
Wilcoxon W & 581.000 \\
Z & -0.388 \\
Asymp. Sig. (2-tailed) & 0.698 \\
\hline
\end{tabular}

a. Grouping Variable:

Group

Sig. equals $<=0.05$

There was no significant difference in students' motivation to learn for both the experiment group and control group in this pre-experiment stage. To calculate the effect size, a formula of $r=\mathrm{Z} / \mathrm{sqrt} \mathrm{N}$ was use where according to Cohen (1988), criteria of $0.1=$ small effect, $0.3=$ medium effect, $0.5=$ large effect. The Mann-Whitney $U$ Test revealed no significant difference in motivation to learn of Group A- Experiment $(M d=55, n=24)$ and Group B - Control $(M d=55, n=25)$, where $U=281, Z=-0.388$, $p=0.69$ and $r=0.06$.

To test $\mathrm{H}_{0} 2$, Wilcoxon Signed Rank Test was conducted on students' motivation score in both classes by comparing score for post-experiment to pre-experiment. The findings were described in Table 6 and Table 7 below. 
INTERNATIONAL JOURNAL OF ACADEMIC RESEARCH IN BUSINESS AND SOCIAL SCIENCES Vol. 10, No. 5, May, 2020, E-ISSN: 2222-6990 @ 2020 HRMARS

Table 5. Wilcoxon Signed Rank Test Results on Students' Motivation to Learn (Control Group)

\begin{tabular}{llrrr} 
Ranks & & & & \\
\hline & & $\mathrm{N}$ & Mean Rank & Sum of Rank \\
\hline MotivationAfter- & Negative Rank & $1^{\mathrm{a}}$ & 3.50 & 3.50 \\
MotivationBefore & Positive Rank & $11^{\mathrm{b}}$ & 6.77 & 74.50 \\
& Ties & $13^{\mathrm{c}}$ & & \\
\cline { 2 - 5 } & Total & 25 & & \\
\hline
\end{tabular}

d. MotivationAfter < MotivationBefore

e. MotivationAfter $>$ MotivationBefore

f. MotivationAfter $=$ MotivationBefore

\begin{tabular}{lc}
\hline & $\begin{array}{c}\text { MotivationAfter- } \\
\text { MotivationBefore }\end{array}$ \\
\hline $\mathrm{Z}$ & $-2.832^{\mathrm{a}}$ \\
Asymp. Sig. (2-tailed) & 0.005 \\
\hline \multicolumn{2}{c}{ b. Based on negative ranks. }
\end{tabular}

b. Based on negative ranks.

In the control group, the Wilcoxon Signed Rank Test revealed a statistically significant increase in motivation in learning, $Z=-2.832, p=0.005$, with a medium effect size $(r=0.4)$.

Table 6. Wilcoxon Signed Rank Test Results on Students' Motivation to Learn (Experiment Group)

\begin{tabular}{llrrr} 
Ranks & & & & \\
\hline & & Mean Rank & $\begin{array}{r}\text { Sum of } \\
\text { Rank }\end{array}$ \\
\hline MotivationAfter- & Negative Rank & $0^{\text {a }}$ & 0.00 & 0.00 \\
MotivationBefore & Positive Rank & $24^{\text {b }}$ & 12.50 & 300.00 \\
& Ties & $0^{c}$ & & \\
\cline { 2 - 4 } & Total & 24 & & \\
\hline
\end{tabular}

a. MotivationAfter < MotivationBefore

b. MotivationAfter $>$ MotivationBefore

c. MotivationAfter $=$ MotivationBefore

\begin{tabular}{lc}
\hline & $\begin{array}{c}\text { MotivationAfter- } \\
\text { MotivationBefore }\end{array}$ \\
\hline Z & $-4.291^{\mathrm{a}}$ \\
Asymp. Sig. (2-tailed) & 0.000 \\
\hline
\end{tabular}

a. Based on negative ranks.

In the experiment group, the Wilcoxon Signed Rank Test also revealed a statistically significant increase in motivation in learning, $Z=-4.291, p=0.000$, with a large effect size $(r=0.6)$.

Based on both findings, we could see that there was significant difference in students' motivation to learn for both the experiment group and control group. However, the difference in terms of 
INTERNATIONAL JOURNAL OF ACADEMIC RESEARCH IN BUSINESS AND SOCIAL SCIENCES

Vol. 10, No. 5, May, 2020, E-ISSN: 2222-6990 ㄷ 2020 HRMARS

motivation to learn increased more in the experiment group $(r=0.6)$ than the control group $(r=0.4)$. $\mathrm{H}_{0} 2$ was rejected.

\section{Conclusion}

This study showed that Spaced Learning can help in increasing students' performance and motivation. This study could be extended by testing whether the student's academic background also contributed to their performance and motivation.

As the study of Spaced Learning in Malaysia is still new, this study could serve as a starting point for further dialogues among researchers and educators interested in researching and using new technique in their teaching and learning activities. Aside from that, this study could also be used as an additional literature on the use of Spaced Learning technique in Malaysia, particularly for students in Higher Learning Institutes.

\section{Acknowledgement}

This study was supported by the University Research Grant (2018-0022-107-01) from Universiti Pendidikan Sultan Idris, Malaysia.

\section{Corresponding Author}

Jessnor Elmy Mat Jizat

Faculty of Management and Economics, Universiti Pendidikan Sultan Idris, Malaysia.

Email: jessnor@fpe.upsi.edu.my

\section{References}

Brown, J. S. (2000). Growing Up: Digital: How the Web Changes Work, Education, and the Ways People Learn. Change: The Magazine of Higher Learning, 32(2), 11-20. doi: 10.1080/00091380009601719

Campbell, D. T., \& Stanley, J. C. (1963). Experimental and Quasi-Experimental Design for Research. Hopewell, NJ: Houghton Mifflin Company.

Chun, C., Dudoit, K., Fujihara, S., Gerschenson, M., Kennedy, A., Koanui, B., Ogata, V., \& Stearns, J. (2016). Teaching Generation $Z$ at the University of Hawai'l. Retrieved from https://www.hawaii.edu/ovppp/Leaders/files/2015-2016-Projects/PELP_GenZ_PaperV.6.05.4.16.pdf

Cohen, J. (1988). Statistical power analysis for the behavioral sciences (2nd ed.). Hillsdale, NJ: Lawrence Earlbaum Associates

De Bruyckere, P., Kirschner, P. A., \& Hulshof, C. D. (2015). Chapter 2 - Myths About Learning Urban Myths About Learning and Education (pp. 17-92). San Diego: Academic Press.

Ersoy, E., \& Oksuz, C. (2015). Primary School Mathematics Motivation Scale. European Scientific Journal 11(16), 37-50.

Fields, R. D. (2005). Making Memories Stick. Scientific American, 292(2), 74-81.

Kelley, P., \& Whatson, T. (2013). Making Long-Term Memories in Minutes: A Spaced Learning Pattern from Memory Research in Education. Frontiers in Human Neuroscience, 7, 589. doi: 10.3389/fnhum.2013.00589 
INTERNATIONAL JOURNAL OF ACADEMIC RESEARCH IN BUSINESS AND SOCIAL SCIENCES

Vol. 10, No. 5, May, 2020, E-ISSN: 2222-6990 @ 2020 HRMARS

Levin, D., \& Arafeh, S. (2002). The Digital Disconnect: The Widening Gap between Internet-Savvy Students and Their Schools Washington DC: Pew Internet \& American Life Project.

Levy, Y., \& Ellis, T. J. (2011). A Guide for Novice Researchers on Experimental and Quasiexperimental Studies in Information Systems Research. Interdisciplinary Journal of Information, Knowledge, and Management, 6, 151-161.

Nicoll, R. A. (2017). A Brief History of Long-Term Potentiation. Neuron, 93(2), 281-290. doi: https://doi.org/10.1016/j.neuron.2016.12.015

Oblinger, D. (2003). Boomers, Gen-Xers and Millennials: Understanding the New Students. EDUCAUSE Review(July/August), 37-47.

Prensky, M. (2001). Digital Natives, Digital Immigrants. On the Horizon, 9(5), 1-6.

Prensky, M. (2005). "Engage Me or Enrage Me": What Today's Learners Demand. EDUCAUSE review, 40, 60-64.

Turner, A. (2015). Generation Z: Technology and Social Interest. The Journal of Individual Psychology, 71(2), 103-113.

Xue, G., Mei, L., Chen, C., Lu, Z.-L., Poldrack, R., \& Dong, Q. (2011). Spaced Learning Enhances Subsequent Recognition Memory by Reducing Neural Repetition Suppression. Journal of Cognitive Neuroscience, 23(7), 1624-1633. doi: 10.1162/jocn.2010.21532 